\title{
THE AFRICAN NATIONAL OONGRESS.
}

\section{$[1952-53]$}

In view of the wideppread interest in the present situation in South Africa aroused, among other things, by the campaign of non-violent civil disebedienee embarked upon by the African people, it may be of aseitibanee to your readers in following the march of events in that unhappy land to know eomething about the African National Congress, the organisatio which is primarily responsible for the launching and the direction of the Campaign of Defiance of Unjust Laws, as it is described In South Africa.

There is a sense in which the African National Congress owes its existence to the United States, for Its founder, Dr P ka I Seme, was educated in this country. Seme was born and brought up in Natal on Mission Station of the American Board, Congregational Missionary Society which has its headquarters in Boston, Mass. After receiving his early education in the Mission Schools of that gociety, he came to this country where after a distinguished College career, he won a scholarship to Oxford University. In the Unthted Kingdom he was called to the Bar, and he returned to South Africa shortly after the conaumation of Union be South Africa in 1910. At that time the African people had no organisation which brought together members of different tribes. The political organisations which existed among them were organised on a more or less tribal basis. Thus in Natal among the Zulum to whichbet tribe Pixley Semex himself belonged there was a body known as the Natal Native Congress headed by John L. Dube who had himself received his College education in the United States; in the Transval there were two such bodies the Transvar Wative Congress and the Transvaal Native Organisation, both ofwhich were dominated by the Sothe tribes inhabiting that part of the country; in the Orange Free State there was an Orange Free State Native Association catering principally for the Tswana tribes; in the Cape there was a body known as the Bantu Union for the Xhosa-speaking tribes. After the Boer War of 1899-1.902 there were four spgande British Colonies in South Africa, the Oape Colony, tha Natal, the Transval and the Orange River Colony. It had been the dream of many statesmen and administratoss that a Union of these territories should be brought about, not only for economic reasons but principally in order that the white rulers of Southern Africa might parsue a uniform poliey towards the non-whites in their midst. This dream was fulfilled in May, 1910 when the Union of South Africa was brought into being. The South Africa Act of 1909 in which the Costitution of the Union 
was contained made it quite clear that it was the intention of thite population to make South Africa into a "white man's country". Nembership of Parliament was to be confined to persons of Buropean descent; the exsurhtere right to voto was to be denied to nonaxduxtaxs whites in all parts of the country except the Cape Province where they had enfoyed such rights since 1854. Even in regard to the latter provision made in the Oonstitution for depriving of their voting rights by a two-thirds majority of the two Houses of When
Parliament sitting togetherWhaticans were deprived of their right to participate in ordinary olections in 1936 myxexxnkaxx only 11 melabers of Parliament out of a total of 190 voted against the measure, while the Coloureds--persons of mixed descent--were deprived of their voting rights by a simple majority in 1950.

To return to our subject, when the South Africa Aot was petrag considered by the Britiah Parliament, the non-white groups kack sent a deputation to Great Britain to protest against the 111 iberal proviotions of the Consitution but their reprsentations were of no avai1. It seemed clear that there was nothing for them but to return to their homeland and to organise themselves for the defence of their rights. Seme conceived the idea of establishing an organisation which would endesvour ro weld together the different tribes into a united nation. The only reply in his view to a united white South Africa was a unitod black South Africa. Together wath a group of young Afrioan lawyers who had just recently returned from training overseas he drev up an elaborate soheme for ax mas organisation which would be open to all classes of persons of African descent, ohiefs and comoners,educated and uneducated, professional men and artisans, from all parts of Southern Africa,ineluding the Union of South Africa and the High Commiseiton Territoriee of Basutbland, Beahuanaland Protectorato and Swaziland. In other words they sought bu buil an African nation which would ignore the political divialons set up by the white man which divided one tribe from another or the same tribe under sepandee jurisdictions. Supreme authority in the organiation was to be vested in an annual conference divided Into two Houses, an Upper House of Chiefs and a Lower House of Commoners. It was considere essential that the Chiese, the traditional leaders of the African people, ahould be given a prominent place in the movemaat. At that the Chiefs had not yet been reduced to the position of government servants which they occupy to day under the Native Administration Act of 1927. Consequently some of the most prominent african Ohiefs aupported the 
movement both financially and morally. It was largely through the support of the Chiefs that the African National Congress was able to send two deputations overseas, one to the United Kingdom in 1914 to make representations to the British Government against the Unio Natives Land Act of 1913 which gave effect to the principle of territorial gegregation between black and white. The story of the hardshpss and the disabilities in land matters which that Act imposed upon the African people is told by the then General Secretary of the African National Congress, Solomon T.Plaatje, ihn his wellknown book "Native Life in South Africa". The second deputation in 1919 went to the Paris Peace Conference to plead the cause of the African people in the light of Preaident Wilson's famous principle of 'self-determination for small nations'. Needless to say these deputations proved abortive In the meantime the African National Congress continued to establish branceas in different parts of the country, and to engage in fighting for the protection of the rights of the Africans. At its annual conferences resultions were passed dealing with the various dieabilties under which Africans laboured. These would then be brought the atteation of the Government by means of deputations or correspondence. The derymaratar day-to-day grievances of the people in matters such as proper accommodation on the trains and other means of public conveyance, the iniquitous Pass Laws, curfew regulations, more facilities for the education of African children,etc. In drder to propagate 1 ts point of view the African National Congress pubahsed the flrst multi-lingual newspaper for Africans knvm as "Abantu-Batho". Today there are several such newspapers circulating among Africans but white

largely controdled by a company, the "Bantu Prese Limited"which nas absorbed all the previously independent African nevspapers. In the course of its history the African National Congress has had its ups and downs. Other organisations which sought to supplant It In the African mind have come and gone. Among these may be mentioned the I.O.U., Imorditix a labor movement founded by one of the most dynamic personalities that have yet appeaned among African leaders, Clemetts Kadalie. The Industrial and Commercial Horkers Union(the I.C.U.) swept through the country like a wild fire until it had a membership of teazen 100,000, and many people thought that this meant the end of Congress, but the I.C.U. In time collapeed. Another movement which seemed to challenge the positlon of the African National Congress as the mouthpieee of the African people was the All-African Convention which was establhahed in 1935 as result of the agaitation against Prime 
Minister J.B.M. Hertzog's 3111 a to deprive the Afrlcang in the Cape of the 12 franchise rights. This agitation oulminated in an emergency conference held in Bloemfontein whioh was attended by delegates from polit1cal,social and oultural organisat1ona. When it was that the Conference should vaxkan form a perinane ct organisation, this move was opposed by the leaders of the African Nat1onal Congregs. Nevertheless the new body was formed and is till carrying on a fitful existence in cortain parts of the country. The African llational Congress has in the meantine gone from strength to strength as the only body which stands for African Nat1onal1em. Por many years the Afrioan National Congreas followed a polioy of co-operation with the Government, whilo fighting for tho extenaion of democratic rights to the African people. It was in 1949 at its snmal conference in Bloemfontein that the Congresa finally decided upon a polloy of non-collaboration and non-oooperation with the suthorities. The resolution passod indicated that shencerorth the Congrees Intenddd to work for polltloal independence and total freedom from white domination. In the light of this otend it called upon members of Congregs to resign from the Native Representative Counoll eatablished by tne Union Uovernment under the Hertzog laws of 1935. Ikkm Dr J.S. Moroka, the Fresident-Cieneral of Congreee,and Prof.Z.K. Hatthews Fresident of the Cape Province section of Congress resigned as from January 1,1950. The Government then took the step of Elbx abolishing the Native Roprseentative Counc1l on the ground thet this body had developed into a focal point for demands for equality with the European. In 1 te place the Government hopes to establiah local bodies organised on an ethnic or tribal basis.

A logical development of the policy of non-coperation lo the campaign of ofvil discoedience which was decided upon at the annual confenence of Congress in December, 1951 The Oongress ie satisfied that the African poople have now no alteraative but to emark upon a campaign for the defiance of the unjust laws to which their people are subjected. The Congreas has invitod other non-juropean organisations to join thean in this struggle. The Campaign 18 one of non-violent passive resietance baed on the principles made famous by Mahatma Gland1 who first applied it in South Africa. The Campeign was launohed on Juns 26,1952, and since that t1me thousands of African and Indiene have responded to the hundreds

appal for volunteers and have defled some of the discriminatgry laws such as the Pass laws, the aparthe1d entrances in public places such as railroad etations and post offices, ckex etc. 
In a number of centres the cepacity of the local jalls have already been exceeded by the number of people arrested. Welfare Comalttees have been formed to take sam care of the dependents of those in custody. Funds are being raieed for the carrting on of the struggle manily through a Stamp Fund known as the Million Shilling Freedom Stamp Fund. Contributions towards this fund are being solloived from all sections of the population In South Africa, and even beyond. The Africen people aro the poorest section of the comanity in South Africa.As has been pointed out, xthe bulk of the members "find it extremebly diffloult to was pay their regular dues, however small" and the aximtantranx organlsation has to depend largely on voluntary efrorts for its varlous aervices. The responze of the people to this movezent indicates that the African National Congrese enjoys their confldonce and thet the pollolea pursuod by successive South Afrioan governments have driven them to the point of desperation. It is not poesible to say at this stage what the outcome of the struggle will be, but there is no doubt that with the general awakening of Africans in different parts of the continent of Africa the parkt polioy of white domination and raciel disorimination will find increasing opposition Irora Africans who regard it as sampm incompatible with the principlen of freedor and justice, and a threat to international peace and security.

The leader of the African National Congress at the present is Dr James S. Moroka, a grandson of Ohief Morbira, the flrat African Onief to befriend the Boer emigrants who trakked from the Cape Oolony in 1836 into the 1nterlor in an attempt to get away from Brttish rule with its new-fangled ldeas at the time about the freedom of ataxaxy 8 laves. Dr Moroka received his early education at the famous Lovedale Missionary Institution, and afterwards qualified as a medical doctor at Bdinburgh,Scotland. As a modical practit1oner ho has during the last $3 x$ thirty years built a wide and luorative practice among both whites and non-whites. But although he pays supertax, he is not regarded as a citizen in the land of his birth. Small wonder that he 1 s devoting himself to the cause of freelng South Africa from the curse of racialkz discrmination 